\title{
THE ULTRASTRUCTURE OF THE PORCINE SYNOVIAL MEMBRANE IN THE EARLY POSTNATAL DEVELOPMENT
}

\author{
D. HORKÝ \\ Department of Anatomy, Histology and Embryology, University of Veterinary Science, \\ 61242 Brno
}

Received fune 29, 1989

\begin{abstract}
Horký D.: The Ultrastructure of the Porcine Synovial Membrane in the Early Postnatal Development. Acta vet. Brno, 59, 1990: 111-119.

The synovial membranes of 4 pigs of both sexes were studied at 2 days after birth. The tissue samples were collected from the hip articular capsule and studied by light and electron microscopy.

The synovial membrane of this postnatal period showed 2 to 3 layers of cells separated by synovial matrix. The ultrastructural picture allowed distinction into $A$ and $B$ cells. Their identification was based on the respective proportions of typical cellular organelles, i. e., granular and agranular endoplasmic reticulum, Golgi complex and secretory granules. Occasionally cells were seen which had all signs of A cells but in addition their cytoplasm contained bodies 0.1 to $1.3 \mathrm{um}$ large which were reminiscent of the secretory granules of $B$ cells. This was suggestive of an occurrence of intermediate forms of synovialocytes. The cytoplasm of B cells contained intracytoplasmic filaments.

The ground fibrillar substance of synovial matrix had individual collagen fibrils on the surface. Some fibrils were projecting into the articular cavity. Among synovialocytes were seen bundles of typical collagen fibrils running in various directions. The penetration of collagen fibrils through the cell membrane of $B$ cells and, near their projections, frequent depositions of fine aperiodic filaments were detected. The synovial membrane was not separated by any basal membrane from the subsynovial tissue of fibrous type. Under the synovialocyte layer there were numerous continuous capillaries.
\end{abstract}

Synovial membrane, synovialocytes, matrix synovialis, subsynovial tissue

The structure and the function of healthy synovial membrane have been the subjects of numerous studies over a long period with the first data appearing nearly 250 years ago (Hunter 1743; Bichat 1800; Brodie 1834; Key 1925; Walcott 1927; Stone 1947). Later the microscopic structure of synovial membrane became a topic of interest of many investigators and has been studied under physiological, pathological and experimental conditions in lower mammalian species and in man (a review by Jaffe 1972; Horký 1981; Ghadially 1982).

The submicroscopic techniques opened new insights into the composition of th is functionally important tissue and resulted in a considerable number of studies using various mammals (Langer and Huth 1960; Barland et al. 1962; Wyllie et al. 1964; Davies and Palfrey 1966; Bozděch and Horn 1970; Wassilev 1972, 1974, 1975; Krey and Cohen 1973; Howlet 1974; Watanabe et al. 1974; Cutlip and Cheville 1973; Horký et al. 1975; Fell et al. 1976; Linck and Porte 1978; Horký 1981, 1984; Ghadially 1982; Okada et al. 1981 and others).

The results of investigations of all the authors showed that virtually all studied species had the synovial membrane consisting of two types of synovial cells: a) A or $M$, macrophage-like, cells whose structure is similar to histiocytes. Their phagocytic abilities have been demonstrated by Ball et al. (1964), Cochrane et al. (1965), Fell et al. (1976) and Horký et al. (1974). b) Cells which in most mammals are characterized by a well-developed granular endoplasmic reticulum, a large Golgi complex and the presence of secretory granules. These cells are called B or F (fibro- 
blast-like) cells or S (secretory) cells. Barland et al. (1962) and then other authors have described $B$ cells in various mammalian species (Wyllie et al. 1964; Krey and Cohen 1973; Johansson and Rejnö 1976; Okada et al. 1981; Horký 1981; Graabaek 1984).

With our first investigation into the porcine synovial membrane we found with surprise that this tissue has so far received very litle attention in the pig. Data on the submicroscopic structure have been available only on adult animals but not on prenatal or perinatal pigs. Therefore we paid special attention to the latter periods of development with an objective to gain an insight into the ultrastructure of porcine synovial membrane in relation to ontogeny. This study is concerned with the porcine synovial membrane in the period immediately after birth and gives a detailed description of the structures involved, i. e., synovialocytes and their differentiation, the pattern of fibrillar and amorphous substances of the synovial matrix, subsynovial tissues and the overall appearance of the synovial membrane.

\section{Materials and Methods}

Samples of porcine synovial membranes were collected from 4 animals of both sexes at 2 days after birth. For light and electron microscopy, the tissue was taken in all instances from the hip articular capsule of the animals. Specimens of synovial membrane including part of subsynovial tissue were carefully dissected into strips ( 1 by 1 by $2-3 \mathrm{~mm}$ ) in a drop of fixation solution. The strips were immediately fixed in glutaraldehyde $(300 \mathrm{mmol} / 1)$ in $0.1 \mathrm{M}$ phosphate buffer $\mathrm{pH}$ 7.4) first for 60 , then for $180 \mathrm{~min}$. This was followed by three rinses in fresh $0.1 \mathrm{M}$ phosphate buffer at $\mathrm{pH} 7.4$ and by two fixations in $40 \mathrm{mmol} / 1 \mathrm{OsO}_{4}$ in phosphate buffer ( $\mathrm{pH} 7.4$ ) for 15 and $45 \mathrm{~min}$, respectively. The specimens were dehydrated in a graded acetone series completed with two 30-min baths of absolute acetone. Immersion was performed in the standard method and the tissue was embedded in Durcupan ACM. Polymerization took place in an oven at $60^{\circ} \mathrm{C}$ for three days. Ultrathin sections were cut with an Ultracut Reichert ultramicrotome, stained with lead citrate according to Reynolds or with $1 \%$ uranyl acetate followed by lead citrate. The sections were examined and photographed with a Tesla BS 500 electron microscope. Semithin sections for light microscopic observations were made from the same Durcupan embedded block and stained with $1 \%$ methylene blue and $1 \%$ Azure II.

\section{Results}

\section{Submicroscopic structure of synovial membrane cells}

The structure of synovial membrane in the early postnatal period in the pig largely resembled that of connective tissue. The main components were cells embedded in intercellular matter consisting of amorphous and fibrillar substances. The cells were already specialized in function and distinguished as synovialocytes. Generally, they were found in three layers (Fig. 1) near the synovial membrane surface. Under the synovialocytes, pericytes and numerous capillaries of continuous type were observed (Fig. 1). The intercellular matter at the membrane surface had a structure different from that seen in the deep areas of the synovial membrane. Also the cells showed such variation in the submicroscopic composition of their cytoplasm that it was possible to distinguish two cell types. All Figures are placed at the end of the volume.

Ultrastructure of A cells. Type A cells were most frequently found in the second synovialocyte layer (Figs 1,2). Their shape resembled a spindle or an irregular prism (Figs 1,2 ). The size was about $12 \mu \mathrm{m}$ by $5 \mu \mathrm{m}$.

\section{Nucleus}

This organelle was rather large corresponding in shape to the cell shape. The nuclear envelope sent wide shallow invaginations against the karyoplasm. The perinuclear space was greatly dilated in several areas (Fig. 2). No connection of the outer membrane of the nuclear envelope with the granular endoplasmic reticulum was observed. Chromatin was arranged into a continuous layer, varying in width 
along its course, attached to the inner membrane of the nuclear envelope; it was also seen as few small karyosomes on sections through the nucleus (Fig.2). The nucleolus was a rare finding.

\section{Cytoplasm}

The granular endoplasmic reticulum was observed in the A-cell cytoplasm only as occasional short cisternae (Figs 1,2 ) located mainly at the cell periphery.

The agranular endoplasmic reticulum consisted of numerous vesicles and larger vacuoles placed both at the cytoplasm periphery and near the nucleus (Figs 1,2 ). Some of these bodies attained a size of 0.5 to $1 \mu \mathrm{m}$. There were so many of them that the agranular endoplasmic reticulum gave the cytoplasm a sponge-like appearance (Figs 1, 2).

The Golgi complex was an inconspicuous structure difficult to discern among the vesicles of the agranular endoplasmic reticulum.

Mitochondria were few in number. Frequently, their cristae were seen to form a dense pattern of septa. Shapes of mitochondria were round or mildly oval (Figs 1, 2).

Ribosomes were not seen free in the cytoplasm of A cells. Only occasionally they formed polyribosomes aggregated in rossette or groups of four.

Lys os omes were a regular finding in the cytoplasm of A cells of this period (Figs 1, 1). Their shapes were oval or resembled elongated rods (Figs 1, 2) and their sizes ranged from 0.1 to $1.3 \mu \mathrm{m}$. They were most frequently found in aggregates but some lysosomes were also scattered at the periphery of cytoplasm or among structures of the agranular endoplasmic reticulum (Figs 1,2). They were filled with either medium-osmiophilic or dark homogeneous matter. The lysosomes were reminiscent of secretory granules of B cells of the synovial membrane (see below.)

Cell membrane. The cytoplasm of A cells was found to send large protrusions into the surrounding matrix synovialis. The cell membrane produced numerous folds which on sections presented the cytoplasm, particularly at its periphery, as having the sponge-like appearance mentioned above. These big formations (Figs 1,2 ) were considered a part of the agranular endoplasmic reticulum. Typical pinocytotic vesicles occurred rarely.

Lipid droplets or glycogen were not present in the cytoplasm of A cells.

Ultrastructure of B cells. Type B cells were either irregularly distributed among A cells or arranged at the surface of the synovial membrane (Fig. 1). They were spindle-shaped or oval and their size was identical to that of A cells.

\section{Nucleus}

It had an irregular shape. In some areas the nuclear envelope formed deep and broad invaginations which, in some instances, made the nucleus look as if consisting of lobes (Fig. 3) The perinuclear space was narrow. The inner membrane of nuclear envelope was lined with a continuous layer of chromatin interrupted only at the sites of nuclear pores. The remaining chromatin was diffusely distributed, as seen in the section through the nucleus (Fig. 3). Perichromatin granules. were detected only occasionally and the nucleolus was a rare finding.

\section{Cytoplasm}

The granular endoplasmic reticulum occurred as flat cisternae with 
many ribosomes (Fig. 1). Some of the cisternae were dilated and filled with fine mesh-like medium-osmiophilic material (Fig. 1).

The agranular endoplasmic reticulum presented as smooth vesicles, 0.1 to $0.2 \mu \mathrm{m}$ in size, and occasional vacuoles up to $0.5 \mu \mathrm{m}$ (Fig. 3). Among these smooth endoplasmic reticulum vesicles were infrequently present, they are also termed coated-vesicles (Fig. 3).

The Golgi complex showed dilated cisternae with homogeneous content. It gave rise to vesicles ranging in size from 0.5 to $1.5 \mu \mathrm{m}$ and varying in the density of their finely granulated content. These vesicles then functioned as secretory granules, typical structures of B-cell cytoplasm. They were usually found aggregated in one region (Fig. 3) or present in the long protrusions of B cells (Fig. 1).

Mitochondria were in greater numbers than in the A-cell cytoplasm and also showed a greater variety in shapes, from oval to rod-lide forms with long cristae (Fig. 3). In some mitochondria the matrix was clear.

Ribosomes had the same pattern as in the A-cell cytoplasm. Lipid droplets, glycogen or cilia were not observed in the cytoplasm of B cells.

Cell membrane. The cytoplasm of $\mathbf{B}$ cells occasionally produced short but broad projections (Fig. 1). Apart from these, the surface was smooth with a few pinocytotic vesicles which, however, were still more frequent than in A cells. B-cell projections contained large amounts of granular cytoplasmic reticulum, occasional mitochondria and secretory granules but also, in some instances, lysosomes and intracytoplasmic filaments (Fig. 4). On rare occasions the penetration of procollagen fibrils through the cell membrane was detected (Fig. 4).

\section{Submicroscopic structure of synovial matrix}

In this period of development the synovial matrix had more ground amorphous substance than the fibrillar one (Fig. 1). The amorphous substance consisted mostly of the protein-hyaluronic acid complex and sulphonated mucopolysaccharides. Both components presented in the electron micrographs as finely granulated medium-osmiophilic material filling the spaces between collagen fibrils. It has been suggested that both the protein-hyaluronic acid complex and the mucopolysaccharides pass into the synovial fluid.

The ground fibrillar substance was composed of two fibrillar structures. The one type presented as typical collagen fibrils, 100 or more $\mathrm{nm}$ wide and up to several $\mu \mathrm{m}$ long. They branched only ocassionally and their periodicity was characteristic of collagen fibrils, i. e. about $64 \mathrm{~nm}$. The other type appeared as aperiodic fibrils about $50 \mathrm{~nm}$ wide and 0.1 to $0.5 \mu \mathrm{m}$ long. This fibrillar type has been seen in the synovial matrix in varying proportions in relation to the mammalian species, the stage of ontogenic development and the state of the joint. In the period under study the ground amorphous substances included typical collagen fibrils which showed different patterns of arrangement near the surface and in the deeper parts of the synovial membrane. The collagen fibrils at the surface (Fig. 1) were isolated and their orientation was irregular. Some were even seen to protrude partly into the articular cavity. In deeper parts among synovialocytes the collagen fibrils formed bunches which could be observed in cross, longitudinal and oblique sections (Figs 1, 3, 4). The well-known fact that the both components of the intercellular matter are produced by synovialocytes was demonstrated, on the one hand, by the close relationship of collagen fibrils to the cell membrane of A and B cells (Figs 2,3 ) and then particularly by the penetration of collagen fibril precursors through the B cell membrane, as clearly presented in our micrographs (Fig. 4). 
In addition, the cytoplasmic projections of synovialocytes were surrounded with bunches of fine fibrillar material (Fig. 4) which, in our view, could be nonpolymerized procollagen filaments.

Submicroscopic structure of subsynovial tissue

The structure of subsynovial tissue differed from site to site in the same joint relation to the respective proportions of cells and the ground amorphous and fibrillar substance. In the past, these criteria provided the basis for classification into fibrous, fibrous-adipose and adipose subsynovial tissues. According to the latest observations only two types are distinguished, namely, fibrous and adipose tissues (Ghadially 1983). In view of the fact that in most mammalian species the synovial membrane does not show a basal membrane separating the cells of synovial membrane from the structures lying below (Barland et al. 1962; Bozděch and Horn 1970; Horký 1981, 1984) it was very difficult to detect the boundary between the synovial membrane proper and the subsynovial tissue because the deep layers of the membrane continued into the underlying tissue. The boundary could be considered the region where under A or B cells of the synovial membrane the typical fibrocytes, or even macrophages, followed a course parallel to the surface (as in Fig. 3). In the normal synovial membrane of some mammals even mastocytes were found in this position and in the postnatal pig under study the parallel course was followed by numerous capillaries.

The ground fibrillar substance was seen as thick bundles of collagen fibrils with a typical periodicity. The bundles ran in various directions so that they could be observed in longitudinal, tangential and cross sections. Aperiodic fibres in the subsynovial tissue were not demonstrated.

The amount of ground amorphous substance among the bundles of collagen fibres varied. Electron micrographs usually showed an uneven mesh of medium-electron density. The total amount was dependent on the number of collagen fibrils and their aggregation into bundles.

According to the characteristics revealed by these observations, the subsynovial tissue of the postnatal pig was classified as fibrous tissue.

\section{Discussion}

Our results showed that the synovial membrane in the early postnatal period of the pig was very similar to that of the adult period of various mammals as has been reported, for instance, by Langer and Huth (1960), Barland et al. (1962), Ghadially and Roy (1966), Bozděch and Horn (1970), Cutlip and Cheville (1973), Fell et al. (1976), Krey et al. (1976), Linck and Porte (1978), Okada et al. (1981), Horký (1981, 1984). Differences in structure have been found in the rat where Roy and Ghadially (1967) and Wassilev (1972, 1973, 1975) in particular, all have described the synovial membrane with a conspicuous accumulation of cells accompanied by a concomitant reduction in synovial matrix.

The synovial membrane in the pig has been studied by Fell et all. (1976) who examined its structure, including its phagocytic ability, by light and electron microscopy both in vivo and in vitro. No data, however, have been reported on the structure of synovial membrane in either prenatal or perinatal porcine periods. The findings of this study can be to a certain extent compared only with our observations of this structure in cattle in the prenatal and early postnatal periods (Horký 1984) and in the pig in the prenatal period (Horký 1989). 
A characteristic feature of the porcine synovial membrane in the prenatal period is a mixed population of incompletely differentiated cells which cannot be distinguished into typical A and B cells (Horký 1989). In the postnatal period reported here the differentiation of cells progressed to such a degree that types of synovialocytes could be discerned, even if in some cases the differentiation was not fully completed. The differentiation was made possible by the ultrastructural appearance of the cytoplasm which had the right proportions of organelles typical of differentiated cells. A slightly more difficult was to evaluate the presence of secretory granules. These granules have already been reported (Wyllie et al. 1964; Ghadially and Roy 1969; Linck and Porte 1978; Graabaek 1984) in various animal species in adulthood and in prenatal periods (Horký 1981, 1984). These secretory bodies have been given various names and also opinions on their origin, composition and function have been diverse. The work of Linck and Porte (1978) and particularly Okada et al. (1981) and Graabaek (1984) has provided evidence that the development of secretory granules is significantly associated with the granular endoplasmic reticulum and the Golgi complex, i. e. the cellular organelles whose specific role in the synthesis and extrusion of secretion has been demonstrated in other cell types (Ghadially 1983). Okada et al. (1981) and Graabaek (1984) reported that the secretory granules of B cells did not contain acid phosphatase (in contrast to the lysosomes of A cells) but possessed mucopolysaccharides and glycoproteins bound to a protein carrier, which could be demostrated by protein digestion. Nevertheless, a clear proof of the release of secretory granules content into the synovial fluid has not been provided. For this reason the involvement of secretory granules in joint lubrication and friction reduction still remains a mere assumption in spite of the views of some authors (such as Graabaek 1984). In the tissues under study, bodies with characteristics of the B cells of the secretory granules of adult synovial membrane were observed also in cells which had all other signs of A cells. These results concerning the early postnatal development of synovial membrane in pigs together with the previous work of Linck and Porte (1978), Okada et al. (1981), Fell et al. (1976) and our earlier studies (Hor ký et al. 1975; Horký 1981, 1984, 1989) give a strong support to the view that mutual transformation of $A$ and $B$ cells is possible and is related to the mammalian species and the age and physiological condition of the joint (Cutlip and Cheville 1973; Horký 1984). The possibility of the A-B cell transformation has also been considered by the authors mentioned above; Linck and Porte (1978) and Fell et al. (1976) write that this phenomenon suggests functional flexibility of the synovial membrane without a loss of the cell function. A reliable distinction between the granules in A and B cells can be achieved only by protein digestion allowing discrimination between lysosomes and secretory granules. This method was not included in our experiments and therefore we will not discuss the nature of the formations observed in synovialocytes.

In contrast to the cells of the foetal synovial membrane, synovialocytes of the postnatal period showed the presence of intracytoplasmic filaments. These were observed predominantly in the B-cell protrusions. As reported in our earlier work on the foetal porcine synovial membrane (Horký 1989), no basal membrane is formed between the synovial membrane and the subsynovial tissue. In the bovine synovial membrane of the prenatal period (Horký 1984) and in the pig at the same stage of development as well as after birth we demonstrated the passsage of collagen fibres through the cell membrane always in B cells. This implies that their designation as S, secretory, cells (Graabaek 1984) based on their ability 
to produce secretory granules and amorphous and fibrillar substances of the intercellular matrix is fully justified.

The surface arrangement of the synovial membrane and the fibrous subsynovial tissue was not found to differ from the adult animals of the other mammalian species.

\section{Ultrastruktura synoviální membrány prasete $\mathrm{v}$ časném postnatálním období}

Byla studována synoviální membrána 4 jedinců obojího pohlaví stárí 2 dny po narození. Vzorky tkáně byly odebírány ve všech případech $z$ pouzdra kyčelního kloubu a pro účely světelné a elektronově mikroskopické histologie byly zpracovány obvyklým způsobem.

Synoviální membrána $\mathrm{v}$ tomto období vývoje je tvořena $2-3$ vrstvami buněk, mezi kterými je synoviální matrix. Buňky lze na základě jejich ultrastruktury rozlišit na A a B typy. Jejich identifikace je umožněna kvantitativními rozdily v zastoupení typických buněčných organel, tj. granulárního a agranulárniho endoplasmatického retikula, Golgiho komplexu a sekrečních granul. Pozorovali jsme i buňky, které měly všechny znaky $\mathrm{A}$ buněk, ale $\mathrm{v}$ cytoplasmě obsahovaly navíc tělíska velikosti $0,1-1,3 \mu \mathrm{m}$ vzhledem identická se sekrečními granuly $\mathrm{B}$ buněk. To svědči o výskytu přechodných forem synovialocytů. V cytoplasmě B buněk se vyskytují intracytoplasmatická filamenta.

Vláknitá složka synoviální matrix je tvořena na povrchu jednotlivými kolagenními fibrilami, které jsou zčásti demaskovány a prominuji do kloubní dutiny. Mezi synovialocyty probíhají svazky typických kolagenních fibril různými smëry. Zachytili jsme průnik kolagenních fibril buněčnou membránou $\mathrm{B}$ buněk a $\mathrm{v}$ blízkosti jejich výběžkư jsou často uloženy svazky jemných aperiodických filament. Synoviální membrána není oddělena basální membránou od subsynoviálni tkáně fibrosního typu. Pod vrstvou synovialocytů probíhají četné kapiláry souvislého typu.

\section{Ультраструктүра синовальной мембраны свиней в ранний постнатальный период}

Проводили изучение синовиальной мембраны 4 особей обоего пола в возрасте 2 суток после опороса. Отбор образцов ткани во всех случая проводили из сумки тазобедренного сустава и для целей световой и электронно-микроскопической гистологии их обрабатывали обычным способом.

Синовиальная мембрана в данный период развития состоит из $2-3$ слоев клеток, между которыми находится синовияльный ростьовый слой. Клетки на основе их ультраструктуры можно разделить на типы А и В. Их идентификации способствует количественная разница присутствия типичных клеточных органелл, т. е. гранулярной и агранулярной эндоплазматической сетки, комплекса Гольджи и секреторных гранул. Нами наблюдались также клетки со всеми признаками клеток $A$, однако с добавочным содержанием в цитоплазме телец размером 0,1 - 1,3 мкм, на вид идентичных с секреторными гранулами клеток В. Это свидетельствует о наличии переходных форм синовиалоцитов. В цитоплазме клеток В встречаются интрацитоплазматические нитки. 
Волокнистая составляющая синовиальных ростковых слоев на поверхности состоит из отдельных коллагеновых фибрилл, отчасти обнаруженных и выходящих в суставную полость. Между синовиалоцитами проходят в разных направлениях пучки характерных колагеновых фибрилл. Нами было установлено проникновение коллагеновых фибрилл клеточной мембраной клеток В и расположение вблизи их выступов пучков тонких апериодических ниток. Синовиальная мембрана не отделена базальной мембраной от субсиновиальной фиброзного типа ткани. Под слоем синовиалоцитов проходят многочисленные капилляры сплошного типа.

\section{References}

BALL, J.-CHAPMAN, J. A.-MUIRDEN, K. D.: The uptake of iron in rabbit synovial tissue following intraarticular injection of iron dextran. A light and electron microscope study. J. Cell Biol., 22, 1964, 355-365.

BARLAND, P. - NOVIKOFF, A. B. - HAMERMANN, D.: Electron microscopy of the human synovial membrane. J. Cell Biol., 14, 1962, 207-220.

BICHAT, M.: In STONE, K.: In: Disease of the joints and rheumatism. Heinemann, Londen, 1947.

BOZDĚCH, Z.-HORN, V.: Die funktionelle Regeneration nach Synovektcmie im Exferiment. Z. Ortop., 108, 1970, 98-104.

COCHRANE, W.-DAVIES, D. V.-PALFREY, A. J.: Absorptive functions of the synovial membrane. Path. Biol., 18, 1970, 601-611.

CUTLIP, R. C.-CHEVILLE, N. F.: Structure of synovial membrane of sheep. Am. J. Vet. Res., 34, 1973, 45-50.

DAVIES, D. V.-PALFREY, A. J.: Electron microscopy of normal synovial membrane. In: Studies on the Anatomy and Function of Bone and Joints, Ed. Evans, F. G., Springer-Verlag, Berlin, 1966.

FELL, K. B. - GLAUERT, A. M.-BARRAT, M. E.' J.-GREEN, R. E.: The pig synovium. I. The intact synovium in vivo and in organ culture. J. Anat., 122, 1976, 663-680.

GHADIALLY, F. N.: Ultrastructural pathology of the cell and matrix. London, Butterworths 1982.

GHADIALLY, F. N.: Fine structure of synovial joints., London, Butterworths, 1983.

GHADIALLY, F. N-ROY, S.: Ultrastructure of rabbit synovial membrane. Ann. Rheum. Dis., 25, 1966, 308-326.

GHADIALLY, F. N.-ROY, S.: Ultrastructure of synovial joints in health and disease. Appleton-Century Crofts, New York, 1969.

GRAABAEK, M. P.: Characteristics of the two types of synoviocytes in rat synovial membrane. An ultrastructural study. Lab. Invest., 50, 1984, 690-702.

GRAABAEK, M. P.: Fine structure of the lysosomes in the two types of synoviocytes of normal rat synovial membrane - a cytochemical study. Cell Tiss. Res., 239, 1985, 293-298.

HORKÝ, D.: Submicroscopic structure of the human synovial membrane. Acta vet. Brno, 50, $1981,3-25$.

HORKY, D.: Ultrastructure of the bovine synovial membrane in ontogenesis. Acta vet. Brno, 53, 1984, 170-117.

HORKÝ, D. - BOZDËCH, Z.-HORN, V.: Ultrastructure of the synovial membrane and the joint cartilage in haemophilia observed in a transmission and scanning electron microscope. Acta Fac. Med. Univ. Brun., 52, 1975, 195-210.

HORKÝ, D.: The Ultrastructure of Synovial Membrane in the Prenatal Pig. Acta vet. Brno, 59, 1990: $13-21$

HORKÝ, D.-BOZDĚCH, Z.-HORN, V.: Ultrastructure of synovial membrane and articular cartilage in haemophilia in the transmision and scanning electron microscope. Folia Morphol. (Prague), 22, 1974, 330-334.

HOWLETT, C. R.: Pathology of coxofemoral arthropathy in young beef bulls: ultrastructure of synovium. Pathology, 6, 1974, 19-28.

HUNTER, W.: In. STONE, K. In: Disease of the joints and rheumatism. Heinemann, London, 1947. 
JAFFE, H. L.: Metabolic, degenerative and inflammatory diseases of bones and joints. München-Berlin - Wien, Urban and Schwarzenberg, 1972.

JOHANSSON, H. E.-REJNÖ, S.: Light and electron microscopic investigation of equine synovial membrane. A comparison between health intraarticular fractures and osteochondrosis dissecans. Acta Vet. Scand., 17, 1976, 153-168.

KEY, J. A.: The reformation of synovial membrane in the knees of rabbits after synovectomy. J. Bone Jt Surg., 7, 1925, 793-815.

KREY, P. R.-COHEN, A. S.: Fine structural analysis of rabbit synovial cells. I. The normal synovium and changes in organ culture. Artritis Rheum., 16, 1973, 324-340.

KREY, P. R.-SCHEINBERG, M. A.-COHEN, A. S.: Fine structural analysis of rabbit synovial cells. II. Fine structures and rosetteforming cells of explant and monolayer cultures. Artritis Rheum., 19, 1976, 581-592.

LANGER, E.-HUTH, F.: Untersuchungen über den submikroskopischen Bau der Synovial Membrane. Z. Zellforsch, 51, 1960, 545-549.

LINCK, G.-PORTE, A.: B-cells of the synovial membrane. I. A comparative ultrastructural study in some mammals. Cell Tiss Res., 187, 1978, 251-261.

OKADA, Y. - NAKANISHI, I. - KAJIKAWA, K.: Secretory granules of B-cells in the synovial membrane. An ultrastructural and cytochemical study. Cell Tiss. Res., 216, 1981, $131-141$.

ROY, S. - GHADIALLY, F. K.: Ultrastructure of normal rat synovial membrane. Ann. Rheum. Dis., 26, 1967, 26-38.

WALCOTT, W.E.: Regeneration of the synovial membrane following typical synovectomy. J. Bone Surg., 9, 1927, 67-78.

WASSILEV, W.: Electron microscopical studies on the development of synovial cells in the knee joint of the rat. Verh. Anat. Ges., 67, 1972, 387-392.

WASSILEV, W.: Ultrahistochemical localization of adenosine triphosphatase activity in the synovial membrane of rats. Histochemie, 37, 1973, 113-117.

WASSILEV, W.: Changes in the ultrastructure of the synovial membrane during growth and aging. Verh. Anat. Ges., 69, 1975, 627-431.

WATANABE, H. - SPYCHER, M. A.-RÜTTNER, J. R.: Ultrastructural study of the normal rabbit synovium. Pathol. Microbiol., 41, 1974, 283-292.

WYLLIE, J. C. - MORE, R. H. - HAUST, M. D.: The fine structure of normal guinea-pig synovium. Lab. Invest., 13, 1964, $1254-1263$. 
Plate VIII.

Horký D.: The Ultrastructure of ... pp. 111-119.

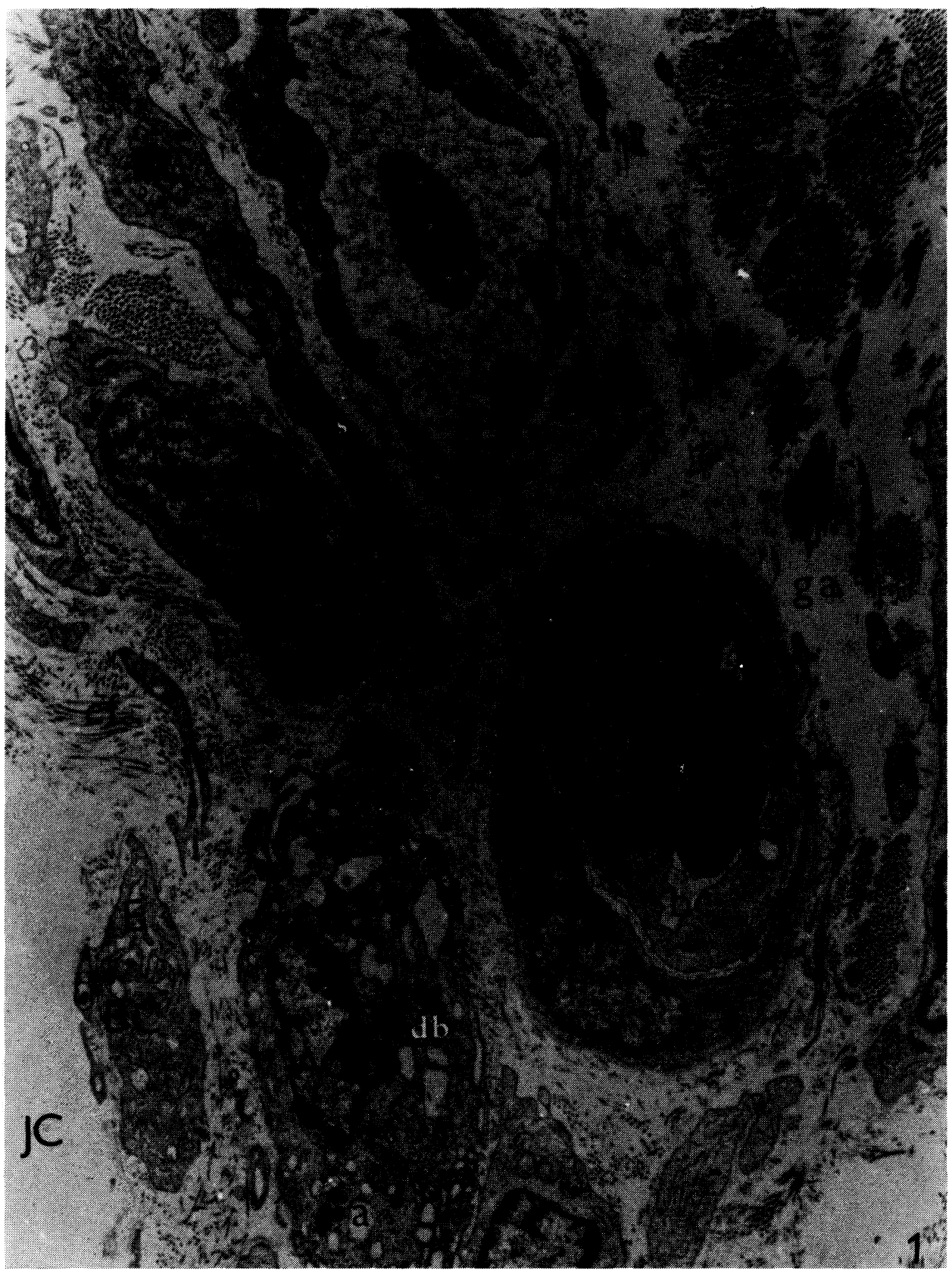

Fig. 1 Porcine synovial membrane with a part of subsynovial tissue. A cells (AC), B cells (BC), capillaries (bs), a pericyte $(\mathrm{P})$, granular endoplasmic reticulum $(\mathrm{E})$, agranular endoplastic reticulum (a), dark bodies (db), secretory granules (s), mitochondria (M), collagen fibres (cf), ground amorphous substance (ga), articular cavity (JC). Magnification: x6,400. 
Plate IX.

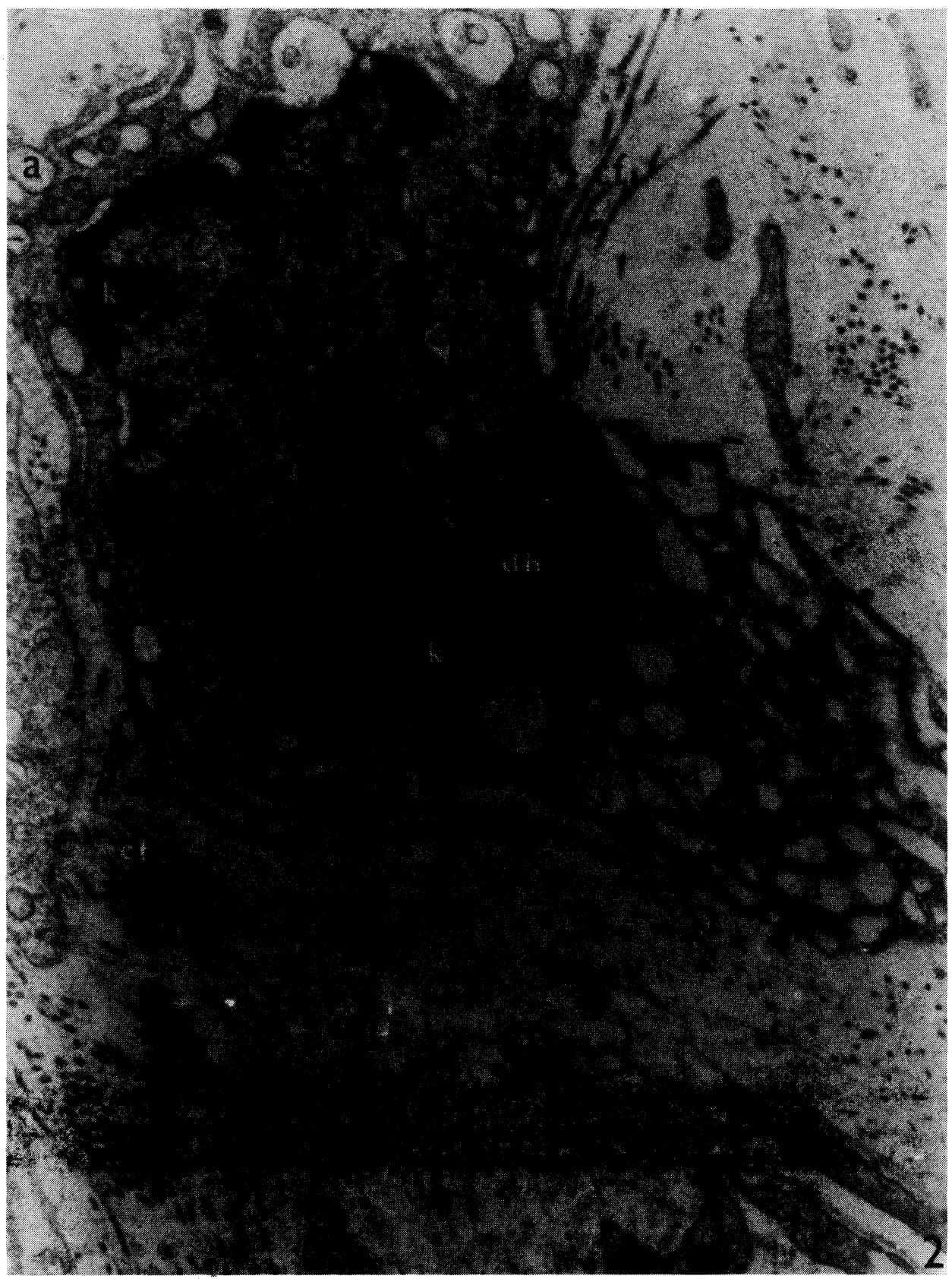

Fig. 2. Type a synovialocyte. Nucleus $(\mathrm{N})$, karyosomes $(\mathrm{k})$, perinuclear space $(-\rightarrow \rightarrow)$, mitochondria $(\mathrm{M})$, granular endoplasmic reticulum $(\mathrm{E})$, agranular endoplasmic reticulum (a), dark bodies (db), collagen fibres (cf), ground amorphous substance (ga), aperiodic fibrils (af). Magnification: $\times 17,000$. 
Plate X.



Fig. 3. Type B synovialocyte with a nucleus (NB) and karyosomes (k). Mitochondria (M), secretory collagen fibrils (k), ground amorphous substance (ga). A connective tissue cell (CC) granules (s), Golgi complex (G), agranular endoplasmic reticulum (a), coated vesicles (cv), bounded by the basal membrane (bm). Magnification: $\times 17,000$. 
Plate XI.

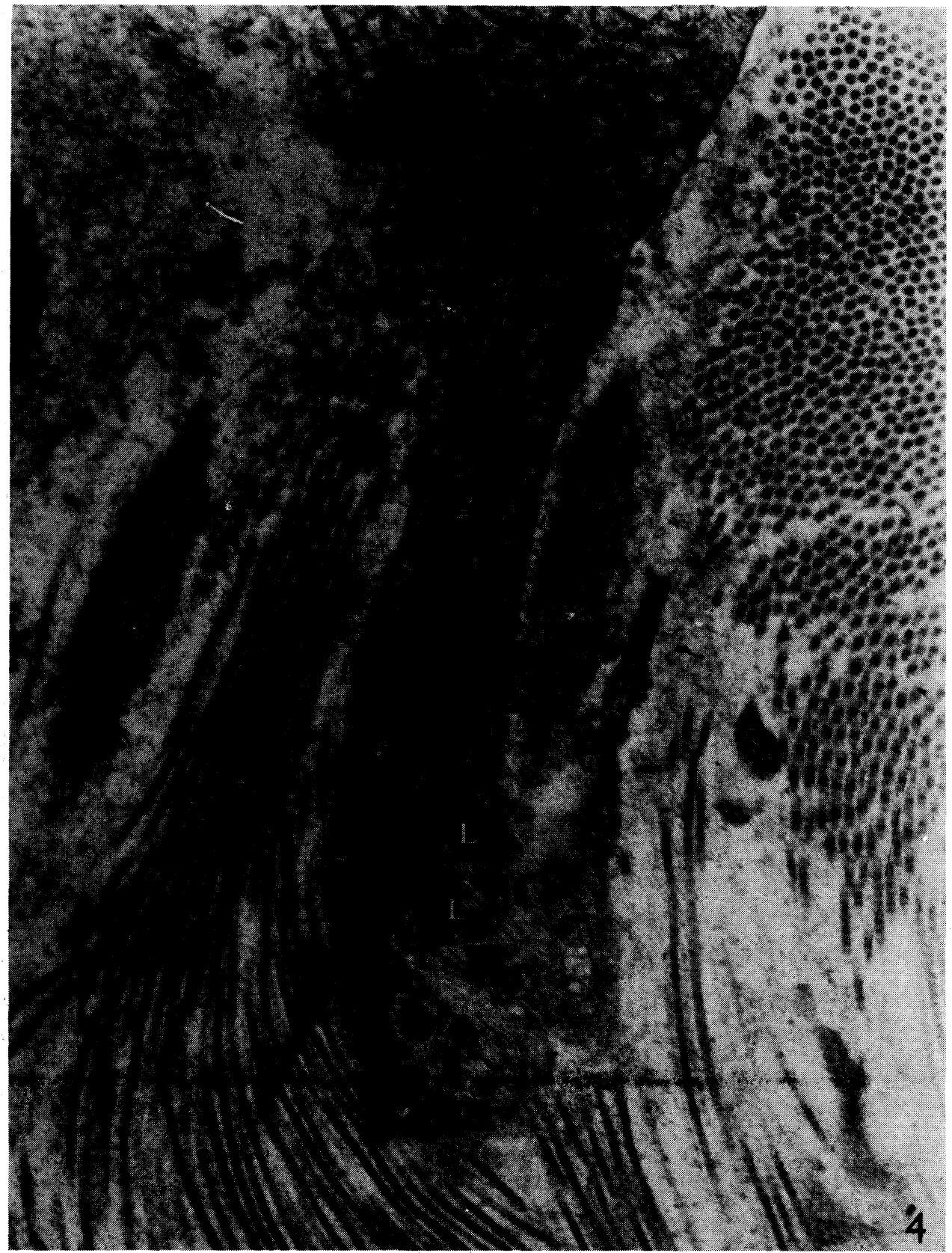

Fig. 4. A broad projection of the B-cell cytoplasm with numerous cisternae of the granular endoplasmic reticulum (E). Intracytoplasmic filaments (if), lysosomes (L), procollagen fibrils penetrating through the cell membrane (pf), collagen fibrils showing periodicity (k), bundles of aperiodic fibrils (ab). Magnification: $\times 21.000$. 